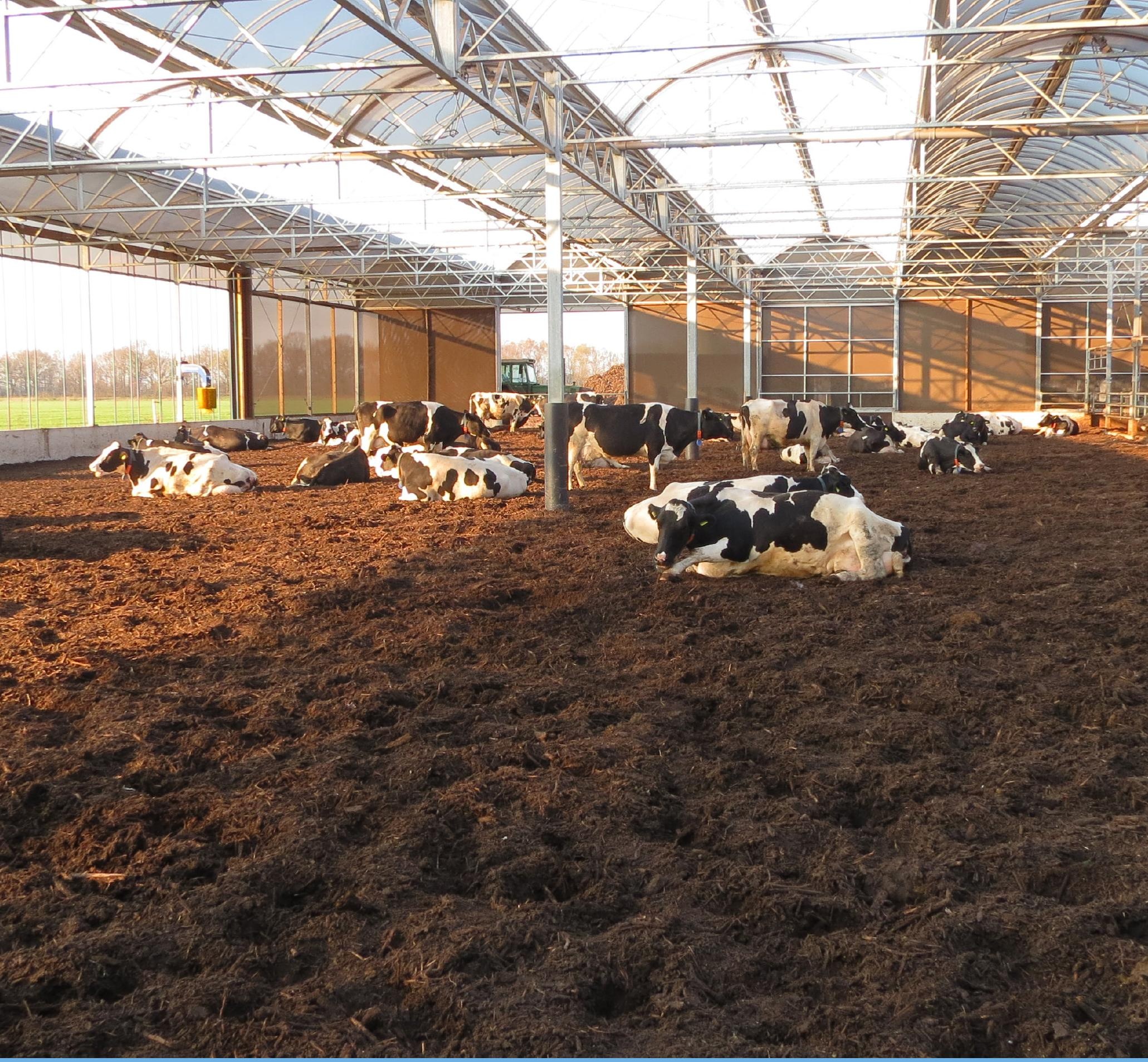

\title{
On farm development of bedded pack dairy barns in The Netherlands
}

Gaseous emissions bedding

H.J.C. van Dooren, P.J. Galama, K. Blanken

\section{WAGENINGEN}

UNIVERSITY \& RESEARCH 



\title{
On farm development of bedded pack dairy barns in The Netherlands
}

Gaseous emissions from bedding

\author{
H.J.C. van Dooren \\ P.J. Galama \\ K. Blanken
}

This research was conducted by Wageningen Livestock Research, commissioned and funded by the Ministry of Economic Affairs, within the framework of Policy Support Research theme

'Sustainable Livestock Husbandry' (project number BO-22.02-012-005))

Wageningen Livestock Research

Wageningen, October 2016

Report 710 
Van Dooren, H.J.C., P.J. Galama, K. Blanken. On farm development of bedded pack dairy barns in The Netherlands, Gaseous emissions from bedding. Wageningen Livestock Research, Report 710.

http://dx.doi.org/10.18174/393409

\section{Samenvatting NL}

Bij vier vrijloopstallen zijn gasvormige emissies uit het ligbed gemeten gebruik makend van de fluxkamermethode. Drie van de vier bedrijven gebruikten groencompost om het ligbed in te strooien. Eén bedrijf gebruikte houtsnippers. De ammoniakemissie per $\mathrm{m}^{2}$ ligbed was beduidend lager dan de emissie per $\mathrm{m}^{2}$ uit een ligboxstal. Maar door het grote oppervlak per dier bedroeg de ammoniakemissie per dier $175 \%-475 \%$ van de emissie uit een ligboxenstal. Ook emissie van lachgas $\left(\mathrm{N}_{2} \mathrm{O}\right)$ waren 3.5 tot 25 keer hoger dan uit een ligboxenstal. De methaanemissie echter was lager en bedroeg 6\%-25\% van de emissie uit een ligboxenstal.

\section{Summary UK}

Gaseous emissions of four bedded pack dairy farms were measured using the flux chamber method. One used wood chips as bedding material, the other three used compost of green waste. Emissions of ammonia per $\mathrm{m}^{2}$ bedding area were considerably lower compared to the concrete slatted floor housing system that acted as a reference system. Due to large area per cow the emissions per cow were however $175 \%-475 \%$ higher compared to the reference system. Emissions of nitrous oxide $\left(\mathrm{N}_{2} \mathrm{O}\right)$ were 3.5 to 25 times higher than typical emission from the reference system. Methane emission however ranged from $6 \%$ to $25 \%$ of the reference system.

This report can be downloaded for free at or at www.wur.nl/livestock-research (under Wageningen Livestock Research publications).

\section{(C) 2016 Wageningen Livestock Research}

P.O. Box 338, 6700 AH Wageningen, The Netherlands, T +31 (0)317 483953 ,

E info.livestockresearch@wur.nl, www.wur.nl/livestock-research. Wageningen Livestock Research is part of Wageningen University \& Research.

All rights reserved. No part of this publication may be reproduced and/or made public, whether by print, photocopy, microfilm or any other means, without the prior permission of the publisher or author.

The ISO 9001 certification by DNV underscores our quality level. All our research commissions are in line with the Terms and Conditions of the Animal Sciences Group. These are filed with the District Court of Zwolle. 


\section{Table of contents}

$\begin{array}{ll}\text { Table of contents } & \mathbf{3}\end{array}$

$\begin{array}{lr}\text { Foreword } & \mathbf{5}\end{array}$

$\begin{array}{ll}\text { Summary } & 7\end{array}$

$\begin{array}{llr}1 & \text { Introduction } & 9\end{array}$

$\begin{array}{lll}1.1 & \text { Scope } & 9\end{array}$

$\begin{array}{lll}1.2 \text { Aim } & 9\end{array}$

$\begin{array}{lrr}2 & \text { Material and methods } & 10\end{array}$

$\begin{array}{lll}2.1 & \text { Farms } & 10\end{array}$

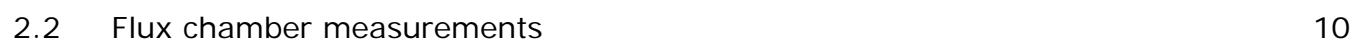

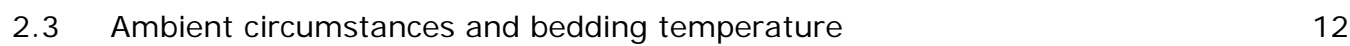

$\begin{array}{llr}3 & \text { Results and discussion } & 13\end{array}$

3.1 General 13

3.2 Ammonia 14

$\begin{array}{lll}3.3 & \text { Greenhouse gasses } & 15\end{array}$

3.3.1 Nitrous oxide emissions 15

3.3.2 Methane emissions 16

$\begin{array}{lll}3.4 & \text { Bedding temperature } & 16\end{array}$

$\begin{array}{llr}4 & \text { Conclusions } & 18\end{array}$

$\begin{array}{lr}\text { References } & 19\end{array}$ 



\section{Foreword}

This report is the third in a series of five reports on the development of bedded pack barns dairy barns in The Netherlands. Three commercial dairy farms were monitored in the years 2010 till mid-2013. This research is a continuation of a tentative study on the feasibility of bedded pack barns and experiments on experimental farms. It is funded by the Dutch Dairy Board and Ministry of Economic Affairs.

The research and the earlier communication concerning the three commercial farms had much impact in the Netherlands and changed the way of thinking about sustainable dairy housing systems. The main focus during the transition from tie stall barns to loose housing systems was on increasing labour efficiency. The increasing interest in bedded pack barns drew attention to improving animal welfare and manure quality. The possible drawbacks of these development are the negative effects on environment and milk quality need to be researched. This report focuses on the gaseous emissions from housing

I want to thank the four dairy farmers Meindert Wiersma, Jeroen Groenewegen, Pascal Peeters and Marc Havermans sincerely for sharing their experiences and for providing data about their farms. As pioneers in the dairy industry they are an example to many others interested in a bedded pack barn and especially for those who have actually built one, in the Netherlands as well as abroad.

Paul Galama

Project leader 


\section{Summary}

One of the aspects of the environmental impact of bedded back barns is the gaseous emissions of Cand $\mathrm{N}$-compounds. These can emit in different forms depending on the processes that take place and circumstances that occur. Most important gasses with environmental impact are ammonia $\left(\mathrm{NH}_{3}\right)$ that leads to acidification and eutrophication and nitrous oxide $\left(\mathrm{N}_{2} \mathrm{O}\right)$, carbon dioxide $\left(\mathrm{CO}_{2}\right)$ and methane $\left(\mathrm{CH}_{4}\right)$ that are greenhouse gasses. Also $\mathrm{N}_{2}$ might emit but has no negative impact on the environment and only represents a loss of valuable nitrogen. The combination of composting processes with a constant input of faeces and urine from the cows walking and lying in these bedded pack barns and a frequent tillage of the upper layer sometimes combined with an aeration system probably influence the nutrient losses through gaseous emissions and make an assessment of these type of barns necessary.

Bedded pack barns in the Netherlands can be divided in two groups. One group uses organic material, mostly compost, as bedding material. Urine is absorbed in that material and faeces is mixed by daily tillage of the top layer with a cultivator or similar device. The other group also uses organic material but with the aim to start a composting process in the bedding. This process should produce enough heat to keep the top layer of the bedding dry. Wood chips are the most used material and urine is partly absorbed and partly evaporated. Faeces are also mixed with the litter but the tillage of the top layer also has the aim to aerate that layer and stimulate the composting processes. In most cases a tractor driven device is used which has a more intensive effect. Some farmers installed an additional aeration system at the bottom of the bedded pack. Some use this to blow outside air upwards through the bedding material, others use it as a suction system to create a downwards airflow through the bedding and concentrate the air at a single emission point. Temperatures in these composting bedded pack barns can rise to more than $60^{\circ} \mathrm{C}$.

Aim of the research was to measure the gaseous emissions of different types of organic bedding for dairy cows and compare these with each other and with known emissions from a reference type of barn.

To compare emissions from different bedded pack barns the flux chamber method has been used. The flux chamber was used as an open flux chamber to measure ammonia fluxes and as a closed flux chamber to measure fluxes of methane, nitrous oxide and carbon dioxide. Besides the emission per $\mathrm{m}^{2}$ from available bedding the results are also presented related to the emission from a reference floor and as emission per cow for the complete housing system related to the reference housing system. The reference floor is defined as a concrete slatted floor with slurry storage in a pit underneath the floor which is the most common floor system in Dutch housing for dairy cattle. An average emission based on flux chamber measurements of $1200 \mathrm{mg} \mathrm{NH} / \mathrm{m}^{2} /$ hour has earlier been reported and was used as reference for the current measured emissions from the different bedding materials.

Four farms were included in this research. One of this farms used wood chips and three used green waste compost from a composting company. The farms are not referred to with names but with numbers. One farm (number 11) left during the project. For that reason results are also presented with and without this farm included. Emissions were measured on 1 to 4 days per farm with 4 measurements per day on different spots in the bedding. In total 48 spots were measured.

The ammonia emission per $\mathrm{m}^{2}$ area available for cows based on flux chamber measurements from a wood chips bedding was $190.4 \mathrm{mg} \mathrm{NH}_{3}$ per $\mathrm{m}^{2}$ per hour and for a compost bedding $372.8 \mathrm{mg} \mathrm{NH}_{3}$ per $\mathrm{m}^{2}$ per hour including farm 11 and $537.1 \mathrm{mg} \mathrm{NH}_{3}$ per $\mathrm{m}^{2}$ per hour without farm 11 .

For farm 1,7 and 8 the emission per $\mathrm{m} 2$ per hour was lower than the emission of ammonia from a reference system. The higher available area per cow however leads to a higher emission per cow. Ammonia emission related to the reference system ( $=100 \%$ ) ranged from $165 \%$ for composting bedding based on woodchips to $476 \%$ for the bedding based on compost.

Nitrous oxide emissions were 3 to 26 times higher than the reference system. 


\section{$1 \quad$ Introduction}

One of the aspects of the environmental impact of bedded back barns is the gaseous emissions of Cand $\mathrm{N}$-compounds. These can emit in different forms depending on the processes that take place and circumstances that occur. Most important gasses with environmental impact are ammonia $\left(\mathrm{NH}_{3}\right)$ that leads to acidification and eutrophication and nitrous oxide $\left(\mathrm{N}_{2} \mathrm{O}\right)$, carbon dioxide $\left(\mathrm{CO}_{2}\right)$ and methane $\left(\mathrm{CH}_{4}\right)$ that are greenhouse gasses. Also $\mathrm{N}_{2}$ might emit but has no negative impact on the environment and only represents a loss of valuable nitrogen.

Gaseous emissions of bedded pack barns have not been measured extensively before. However, emissions of deep litter systems for cows and pigs and other type of litter based systems for dairy and beef cows have been researched. Also emissions during composting are reported frequently. The combination of composting processes with a constant input of faeces and urine from the cows walking and lying in these bedded pack barns and a frequent tillage of the upper layer sometimes combined with an aeration system probably influence the nutrient losses through gaseous emissions and make an assessment of these type of barns necessary. Losses have been quantified by making balances over a long period for the farms described in this report. This was reported earlier by (De Boer, 2013) In this report the direct measurements of gaseous emissions of aforementioned components are described.

Bedded pack barns in the Netherlands can be divided in two groups. One group uses organic material, mostly compost, as bedding material. Urine is absorbed in that material and faeces is mixed by daily tillage of the top layer with a cultivator or similar device. The other group also uses organic material but with the aim to start a composting process in the bedding. This process should produce enough heat to keep the top layer of the bedding dry. Wood chips are the most used material and urine is partly absorbed and partly evaporated. Faeces are also mixed with the litter but the tillage of the top layer also has the aim to aerate that layer and stimulate the composting processes. In most cases a tractor driven device is used which has a more intensive effect. Some farmers installed an additional aeration system at the bottom of the bedded pack. Some use this to blow outside air upwards through the bedding material, others use it as a suction system to create a downwards airflow through the bedding and concentrate the air at a single emission point. Temperatures in these composting bedded pack barns can rise to more than $60^{\circ} \mathrm{C}$.

\subsection{Scope}

Emission measurements have been part of the project from the beginning. After the laboratory experiments in the first phase of the project, emissions were measured using a flux chamber at three research farms in 2009 each with a different bedding material (Van Dooren et al., 2012). In the next, third stage of the project the scope was extended to four practical farms. It is this stage that is reported here. In the meantime the results of the fourth project phase were also already published (Galama et al., 2015).

\subsection{Aim}

Aim of the research was to measure the gaseous emissions of different types of organic bedding for dairy cows and compare these with each other and with known emissions from a reference type of barn. 


\section{Material and methods}

\section{$2.1 \quad$ Farms}

The most important farm characteristics are summarized in Table 1 and Table 2. Among the four farms there is one that use wood chips and three that use green waste compost from a composting company. Detailed description of the farms is given in (Galama, 2013). The farms are not referred to with names but with numbers. These numbers are the same as used in the report of stage four of the project were the research group was extended with 7 farms and one farm (number 11) left the project. For this reason the numbering of the farm is not sequential. Farm 11 was not housing dairy cows on the bedding. For that reason results are also presented not including this farm.

Table 1 Farm characteristics of ten farms using a bedded pack barn (status 2012)

\begin{tabular}{lllll}
\multicolumn{1}{c}{ Farm number } & 1 & 7 & 8 & 11 \\
Bedded pack barn since & Dec ‘09 & June '10 & Aug '10 & July '09 \\
\hline Number of cows (approximately) & 60 & 185 & 80 & -1 \\
\hline Breed & Mainly HF & various & various & HF \\
\hline Bedding material & Wood chips & Compost & Compost & Compost \\
\hline Aeration (woodchips) & Blowing & - & - & - \\
\hline Cows & Lact. + dry & Lact. + dry & Lact. + dry & Dry + young \\
\hline Machine used for top layer & Mill & Mill & Power harrow & Cultivator \\
\hline Number of times/day & 1 & 1 & 2 & 1 \\
\hline Feed alley & yes & no & yes & no \\
\hline Milking system & $2 \times 10$ & AMS & AMS & - \\
\hline Grazing & no & no & no & no \\
\hline
\end{tabular}

${ }^{1}$ only dry cows and young stock

Table 2 Summary of important farm characteristics

\begin{tabular}{lllll}
$\begin{array}{l}\text { Farm } \\
\text { number }\end{array}$ & Material & $\left(\mathrm{m}^{2} / \mathrm{cow}\right)$ & Material & $\left(\mathrm{m}^{2} / \mathrm{cow}\right)$ \\
\hline 1 & Wood chips (WC) & 12.5 & Concrete slats & 5.0 \\
\hline 7 & Compost (C) & 22.0 & None & - \\
\hline 8 & Compost (C) & 9.5 & Concrete slats & 7.0 \\
\hline 11 & Compost (C) & 15.0 & None & - \\
\hline
\end{tabular}

\subsection{Flux chamber measurements}

To compare emissions from different bedded pack barns the flux chamber method has been used. The flux chamber used (Figure 1) had a square measuring area of $5.5 \mathrm{~m}^{2}$ and a cross section height of 0.4 $\mathrm{m}$ resulting in a cross section area of $0.95 \mathrm{~m}^{2}$. On both sides of the flux chamber a triangle shaped duct was mounted to guide the air over the measuring area. Air was coming in and going out through a round flexible tube with a diameter of $0.35 \mathrm{~m}$ (VP-super, Panflex, Ede). A ventilator (Fancom FMS 35) with ventilation control unit (Fancom FCTA) was used to pull the air through the flux chamber and over the measuring area. The ventilator had a maximum capacity of $3,000 \mathrm{~m}^{3} / \mathrm{h}$. Ventilation was set at a constant value of $30 \%$ of the maximum capacity resulting in an average air velocity across the emitting surface of $0.20 \mathrm{~m} / \mathrm{s}$. 
The flux chamber was used as an open flux chamber to measure ammonia fluxes. The ventilator created a constant air flow through the flux chamber. Incoming air was taken from above the bedding at a distance of around 5 meter from the flux chamber. The exhaust point of the outgoing air was also around 5 meter away at the other side of the flux chamber. Ventilation rate was measured using a fan wheel anemometer placed before the ventilator in the outgoing air flow. Both incoming and outgoing air were sampled using a PE sampling line. Concentration of ammonia in incoming and outgoing air was measured using two photo-acoustic multi gas monitors (Innova 1312). Concentrations were measured during 30 minutes. During that period the concentration of ammonia of both incoming and outgoing air was also measured by leading an air sample with a restricted flow of around $1000 \mathrm{ml} / \mathrm{min}$ through two glass impingers placed in serial and both put in $100 \mathrm{ml} 0.5 \mathrm{M}$ sulphuric acid solution. The ammonia emission $(E)$ in $\mathrm{mg} / \mathrm{m}^{2} / \mathrm{h}$ from the measuring area $(A)$ is calculated by multiplying the difference of average ammonia concentration between ingoing $\left(C_{\text {in }}\right)$ and outgoing air $\left(C_{\text {out }}\right)$ with the ventilation rate $(\phi)$ as in formula (1):

$E=\frac{\phi *\left(C_{\text {out }}-C_{\text {in }}\right)}{A}$

The flux chamber was used as a closed flux chamber to measure fluxes of methane, nitrous oxide and carbon dioxide. To close the flux chamber both ends of the flexible tubes were connected. The ventilator created a constant air flow through the flux chamber. Two photo-acoustic multi gas monitors (Innova 1312) were used to measure the concentration of $\mathrm{N}_{2} \mathrm{O}, \mathrm{CO}_{2}$ and $\mathrm{CH}_{4}$ using filters UA0985, UA983 and UA0987 respectively. As the filter used to measure the $\mathrm{N}_{2} \mathrm{O}$ is also sensitive for $\mathrm{CO}_{2}$, influencing the $\mathrm{N}_{2} \mathrm{O}$ reading for one photo-acoustic multi gas monitor the $\mathrm{CO}_{2}$ was filtered from the sampled air using soda lime in granular form. Emission is calculated using the method described by Mosquera et al. (2010):

$E=\frac{\mathrm{V}^{*}\left(C_{1}-C_{0}\right)^{2}}{A * t *\left(2 C_{1}-C_{2}-C_{0}\right)} * \ln \left(\frac{C_{1}-C_{0}}{C_{2}-C_{1}}\right)$

With $V\left[\mathrm{~m}^{3}\right]$ the volume of the box and tubes, $A\left[\mathrm{~m}^{2}\right]$ the measuring area and $\mathrm{C}_{0}$ gas concentration at $t=0$, that is the moment the flux chamber is placed on the emitting surface, $C_{1}$ gas concentration at $t$ and $C_{2}$ the gas concentration at $2 * t$. Gas concentration were measured every 2 minutes ( $t=2 \min$ ).

Besides the emission per $\mathrm{m}^{2}$ from available bedding the results are also presented related to the emission from a reference floor and as emission per cow for the complete housing system related to the reference housing system.

The reference floor is defined as a concrete slatted floor with slurry storage in a pit underneath the floor which is the most common floor system in Dutch housing for dairy cattle. An average emission based on flux chamber measurements has earlier been reported by Dooren et al. (2012) and was based on several measurements. This average emission of $1200 \mathrm{mg} \mathrm{NH} / \mathrm{m}^{2} /$ hour is used as reference for the current measured emissions from the different bedding materials.

The most common housing system for dairy cattle in the Netherlands is the system with cubicles combined with a concrete slatted floor with pits for slurry storage. Based on the average emission from the concrete slatted floor $\left(1200 \mathrm{mg} \mathrm{NH}_{3} / \mathrm{m}^{2} / \mathrm{h}\right)$ and assuming that the emitting area is $4 \mathrm{~m}^{2}$ per cow the calculated emission per cow of this system can be compared with the emission per cow from the compost bedded pack system.

Comparison with the official emission factor published in the Regeling ammoniak en veehouderij (Rav) is not possible as flux chamber measurements are not suitable to base an emission factor for a housing system on. Measurement methods differ and circumstances during the flux chamber measurement are static and not representative for the dynamic circumstances that occur in the barn over a longer time. 

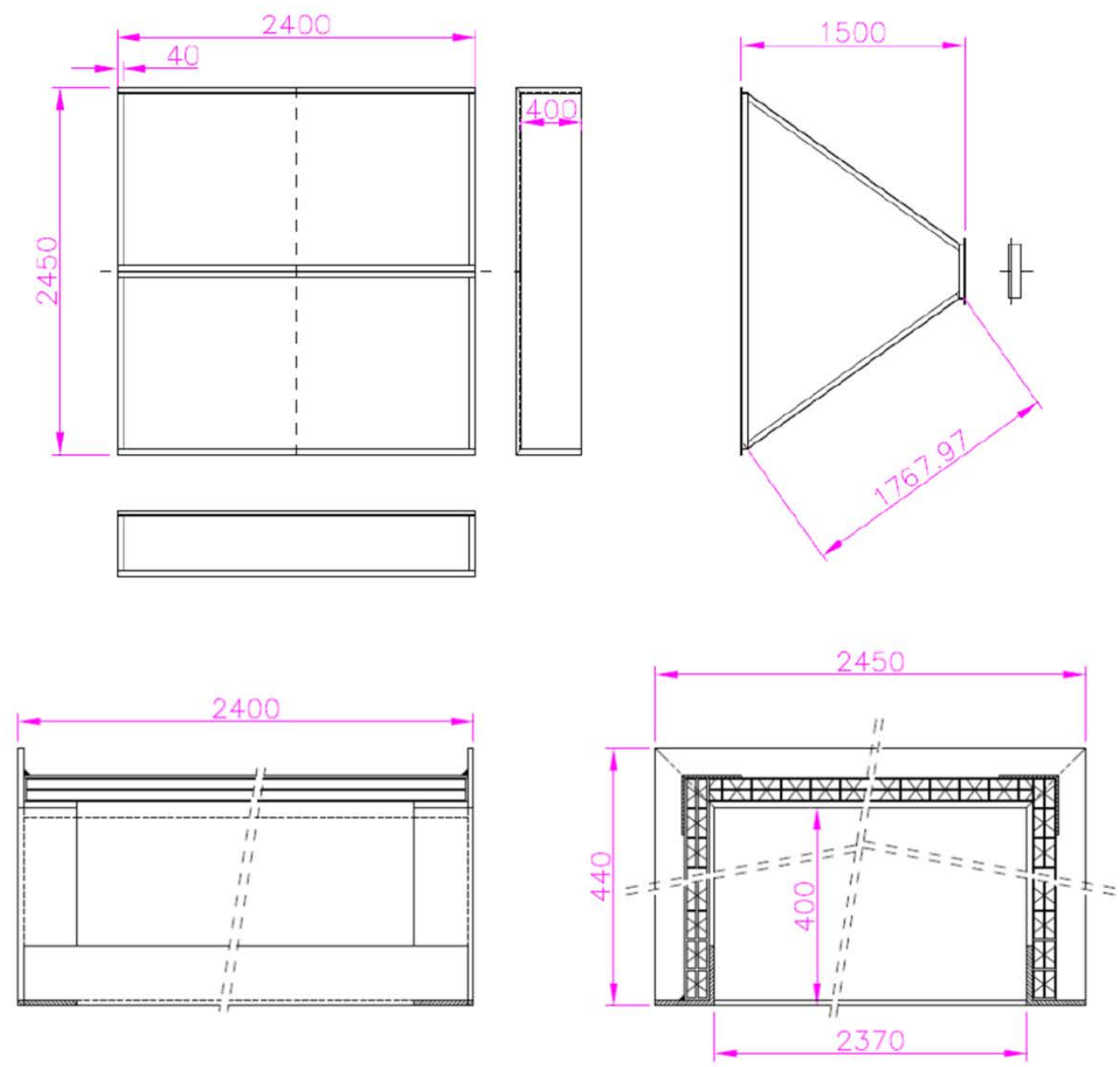

Figure 1 Top view and cross section of flux chamber (dimensions in $\mathrm{mm}$ ).

\subsection{Ambient circumstances and bedding temperature}

During flux chamber measurement the ambient inside barn temperature and relative humidity was recorded using Rotronic T en RH sensors (ROTRONIC Instrument Corp., Huntington, VS) with a precision of $\pm 1.0^{\circ} \mathrm{C}$ en $\pm 2 \%$ respectively. In most cases the bedding temperature around the flux chamber was measured five times at three depths: $0 \mathrm{~cm}, 20 \mathrm{~cm}$ and $40 \mathrm{~cm}$. 


\section{Results and discussion}

\subsection{General}

Measurements took place on 12 different days between 17-3-2011 and 31-7-2012. The number of days and total number of measurement is presented in Table 3 . The same table shows the average ambient temperature inside and outside the barn. The measurement took place in months 3, 7 and 10 reflecting spring, summer and autumn. Real winter conditions are missing. Temperature ranged from 5.7 to $21.4{ }^{\circ} \mathrm{C}$ outside temperatures and 7.2 and 25.6 inside temperatures. Inside temperatures were always a few degree higher than outside temperature which is normal (Figure 2 ).

Table 3 Number of days and measurements per farm

\begin{tabular}{lcccc} 
Farm & Days & Measurement & $\begin{array}{c}\text { Inside } \\
\text { temperature }\end{array}$ & $\begin{array}{c}\text { Outside } \\
\text { temperature }\end{array}$ \\
\hline 1 & 4 & 16 & 15.9 & 12.8 \\
\hline 7 & 4 & 16 & 15.2 & 12.8 \\
\hline 8 & 3 & 12 & 19.1 & 16.4 \\
\hline 11 & 1 & 4 & 10.1 & 7.2 \\
\hline
\end{tabular}

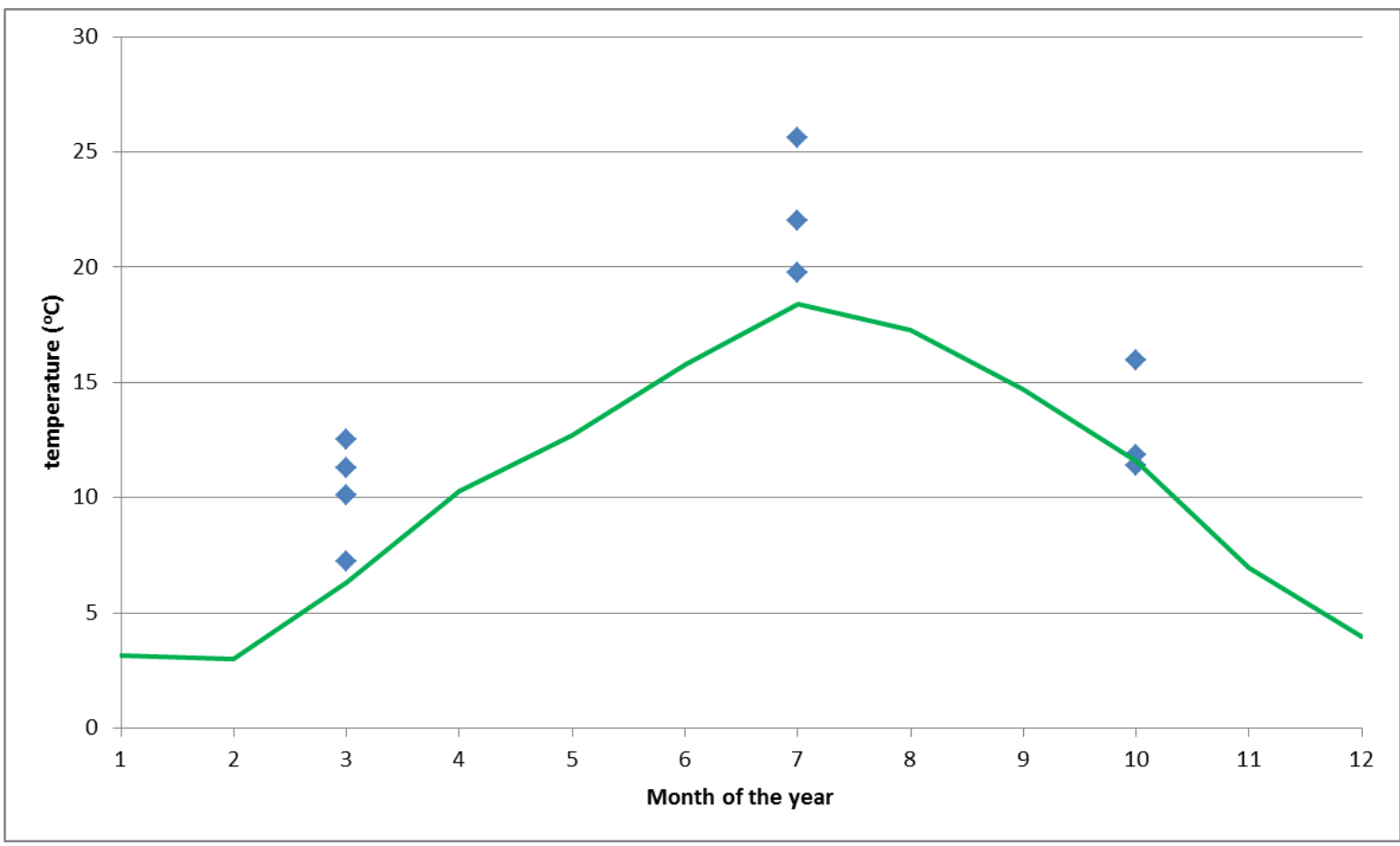

Figure 2 Outside temperature per month (green line) and inside temperature per measurement (blue points). 


\subsection{Ammonia}

The emissions in $\mathrm{mg} \mathrm{NH}_{3}$ per $\mathrm{m}^{2}$ per hour from are presented in table 4.

Table 4 Results of $\mathrm{NH}_{3}$ emission from the bedding in $\mathrm{mg} / \mathrm{m}^{2} / \mathrm{h}$.

\begin{tabular}{lccccc} 
Farm & $\mathrm{n}^{1}$ & $\begin{array}{c}\mathrm{NH}_{3} \\
\text { emission } \\
\left(\text { Innova }{ }^{\mathrm{a}}\right)\end{array}$ & & $\left.\begin{array}{c}\mathrm{NH}_{3} \text { emission }^{2} \\
(1 \text { mpingers }\end{array}\right)$ & se \\
\hline 1 & 16 & 190.4 & 42.9 & 154.2 & 83.8 \\
\hline 7 & 16 & 754.0 & 151.0 & 1037.8 & 140.8 \\
\hline 8 & 12 & 320.1 & 89.4 & 428.7 & 137.8 \\
\hline 11 & 4 & 44.3 & 9.8 & 48.2 & 16.7 \\
\hline
\end{tabular}

${ }^{1} \mathrm{n}=$ number of measurements; ${ }^{2}$ se=standard error; ${ }^{a}$ Multigasmonitor of Lumasense Inc.; ${ }^{b}$ Sampling methods where ammonia is impinged in acid solution

These are the emissions per $\mathrm{m}^{2}$ of bedding area. To compare the results per animal the amount of space per cow (Table 2) need to be considered. The emissions per animal for both the innova and impinger are presented in Figure 3.

To compare the emission from the bedded pack barns with the reference cubicle system with concrete slatted floor the results in Table 4 are calculated to emission per animal using the available lying area per animal from Table 2. This emission is added to the emission per animal from the concrete slatted walking floor (when available) using the $1200 \mathrm{mg} \mathrm{NH3}$ per $\mathrm{m}^{2}$ per hour measured in another project (Van Dooren et al., 2012) and again the available walking area from Table 2. The comparison of the relative emission per animal from the bedded pack barn with the emission from the refence system both based on flux chamber measurements is given in Figure 4.

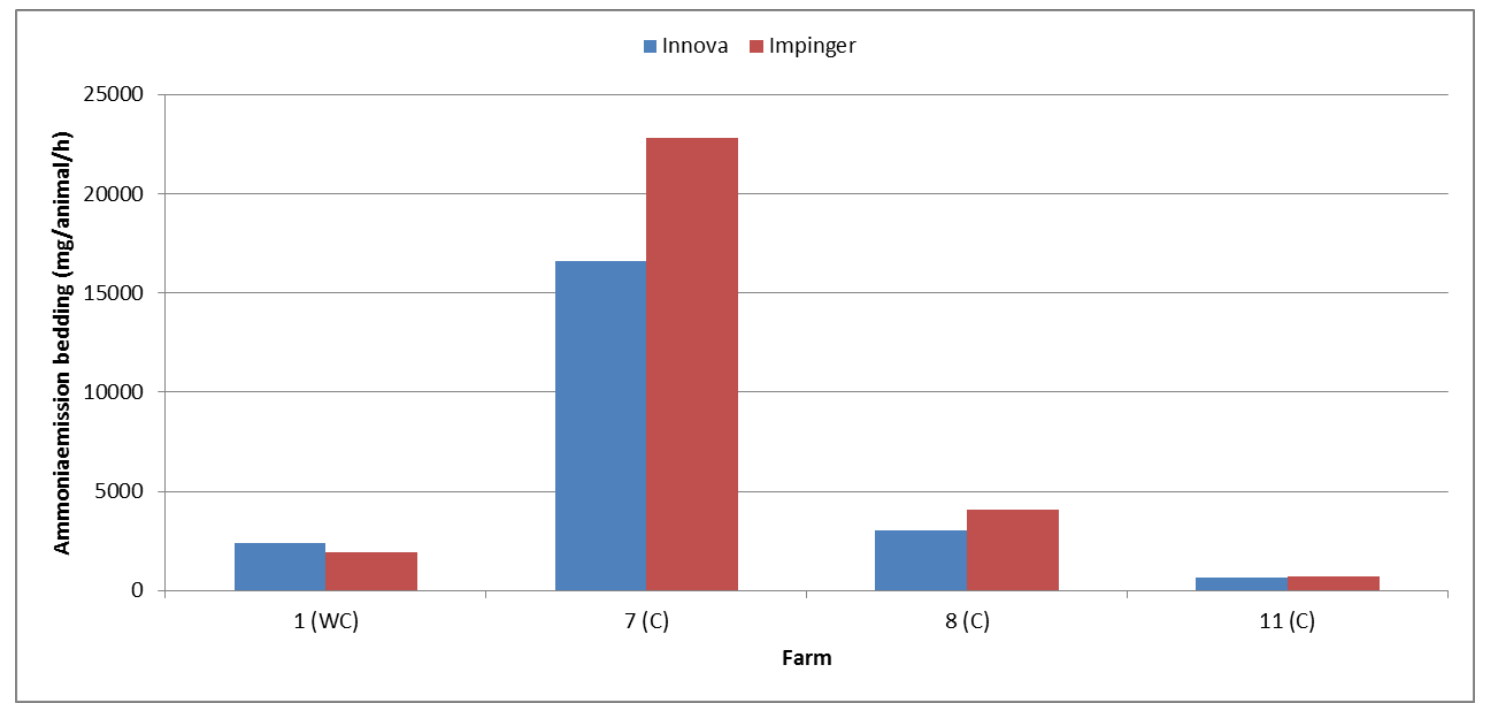

Figure 3 Ammonia emissions per animal per hour from the bedding based on flux chamber measurements.

Emission from farm 11 are very low compared to the other farms and data reported in Galama et al (2015). Reason is that this farmer only housed dry cows and young stock ( $>1$ year) on the bedding. These groups have a much lower $\mathrm{N}$ excretion leading to a lower ammonia emission.

Emission based on innova and impingers were comparable for farm 1 and 8 . Emission based on impinger concentrations were 38\% higher than those based on innova concentration for farm 7. A clear explanation for this difference in not available. Neither for the higher emission level of farm 7 compared to farm 8 although both use compost as bedding material. The emission of the last two measuring days at farm 7 showed much higher emission levels. Moisture content of the bedding or other quality aspects possibly cause these differences. 
The relative emission for farm 1, 7 and 8 are higher than the emission from the reference system with concrete slatted floors ranging from $175 \%$ to $475 \%$. The emission from the compost barns seem to be somewhat higher than the farm with composting wood chips. The level of farm 1 is comparable to that reported earlier in Galama et al. (2012) at the same farm.

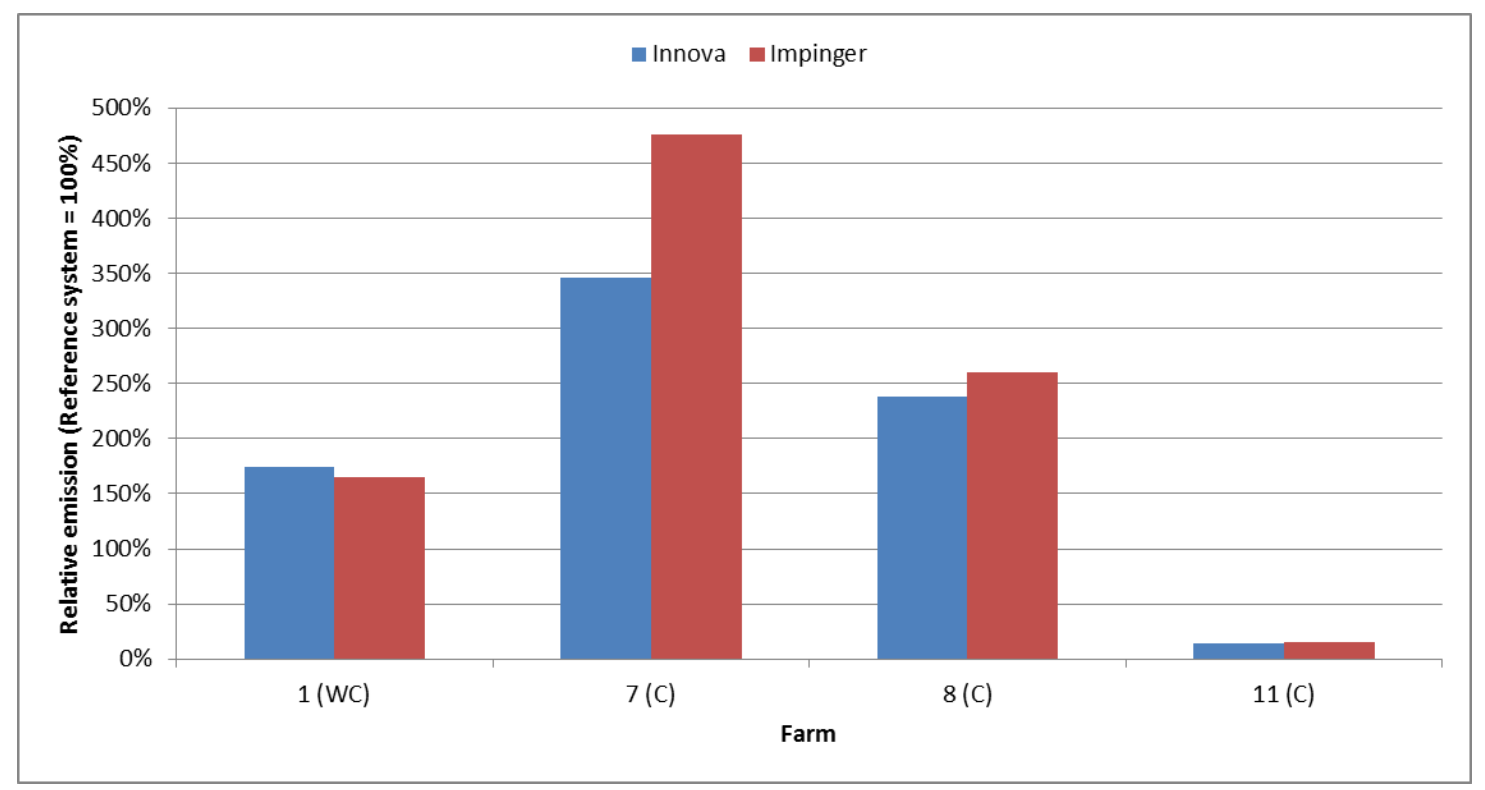

Figure 4 Relative emission per animal from bedded pack barns based on flux chamber measurements and compared to the reference system (cubicle system with concrete slatted floor $=100 \%$ ).

\subsection{Greenhouse gasses}

\subsubsection{Nitrous oxide emissions}

The results of the $\mathrm{N}_{2} \mathrm{O}$ emissions are presented in Table 5 .

Table 5 Results of $\mathrm{N}_{2} \mathrm{O}$ emission per $\mathrm{m}^{2}$ per hour and per animal per year based on available area per cow

\begin{tabular}{lccccc} 
Farm & $n$ & $\begin{array}{c}N_{2} \text { e emission } \\
{\left[\mathrm{mg} / \mathrm{m}^{2} / \mathrm{h}\right]}\end{array}$ & $\mathrm{se}$ & $\begin{array}{c}\mathrm{N}_{2} \text { O emission } \\
{[\mathrm{kg} / \text { animal/ } \mathrm{y}]}\end{array}$ & $\begin{array}{c}\text { Relative } \\
\text { emission }\end{array}$ \\
\hline 1 & 13 & 7.3 & 1.9 & 0.8 & $347 \%$ \\
\hline 8 & 10 & 30.7 & 10.7 & 5.9 & $2569 \%$ \\
\hline 11 & 8 & 33.4 & 17.8 & 2.8 & $1207 \%$ \\
\hline
\end{tabular}

Nitrous oxide $\left(\mathrm{N}_{2} \mathrm{O}\right)$ is a strong greenhouse gas (298 times stronger than $\mathrm{CO}_{2}$ ). It can be formed during biological processes in the bedding especially when both aerobic and anaerobic circumstances are available. Ammonia is transformed to nitrogen gas $\left(\mathrm{N}_{2}\right)$ in two processes called nitrification and denitrification. $\mathrm{N}_{2} \mathrm{O}$ is an intermediate product and can emit. Temperature, $\mathrm{pH}$ and oxygen availability play an important role. The emission of nitrous oxide (laughing gas) from a cubicle system with concrete slatted floor and pits for slurry storage has not been measured before using a flux chamber. Mosquera and $\mathrm{Hol}$ (2012) calculated emission factors for this reference system. This emission factor is $0,23 \mathrm{~kg} \mathrm{~N} \mathrm{~N}_{2} \mathrm{O}$ per animal per year. All farms produced more $\mathrm{N}_{2} \mathrm{O}$ than the reference system up to almost 26 times more. Averaged over bedding material wood chips had a lower emission compared to compost. 


\subsubsection{Methane emissions}

The results of the $\mathrm{CH}_{4}$ emissions are presented in Table 6.

Table 6 Results of $\mathrm{CH}_{4}$ emission from the bedding in $\mathrm{mg}$ per $\mathrm{m}^{2}$ per hour and $\mathrm{kg}$ per animal per year.

\begin{tabular}{lccccc} 
Farm & $n$ & $\begin{array}{c}\mathrm{CH}_{4} \text { emission } \\
{\left[\mathrm{mg} / \mathrm{m}^{2} / \mathrm{h}\right]}\end{array}$ & se & $\begin{array}{c}\mathrm{CH}_{4} \text { emission } \\
{[\mathrm{kg} / \text { animal/ y] }}\end{array}$ & $\begin{array}{c}\text { Relative } \\
\text { emission }\end{array}$ \\
\hline 1 & 13 & 82.1 & 32.5 & 9.0 & $6 \%$ \\
\hline 8 & 14 & 186.7 & 59.0 & 36.0 & $25 \%$ \\
\hline 11 & 10 & 165.8 & 43.6 & 13.8 & $10 \%$ \\
\hline
\end{tabular}

Methane $\left(\mathrm{CH}_{4}\right)$ is a strong greenhouse gas ( 25 times stronger than $\mathrm{CO}_{2}$ ). It can be formed during biological processes in the bedding under anaerobic circumstances. It is produced in several steps from volatile solid available in the bedding or slurry. Intermediate products are volatile fatty acids, and they can be formed and emitted during the complex process. Temperature, $\mathrm{pH}$ and oxygen availability play an important role. However, a more important source of methane are the enteric processes in the rumen of cattle. Roughly $75 \%$ of the total methane emission from a dairy barn comes from the rumen. The emission of methane from a cubicle system with concrete slatted floor and pits for slurry storage has not been measured before using a flux chamber. Mosquera and Hol (2012) calculated emission factors for this reference system. This emission factor is $141,7 \mathrm{~kg} \mathrm{CH} 4$ per animal per year. All farms produced less $\mathrm{CH}_{4}$ than the reference. Averaged over bedding material compost seems to have a somewhat higher methane emission than the wood chips bedding. These results only reflect the emission from the bedding. In all cases the methane from the enteric fermentation should be added to get a comparable emission factor per animal per year!

\subsection{Bedding temperature}

At every flux chamber measurement the bedding temperature was measured at three depts. The average temperature per farm for these three depths is given in Figure 5.

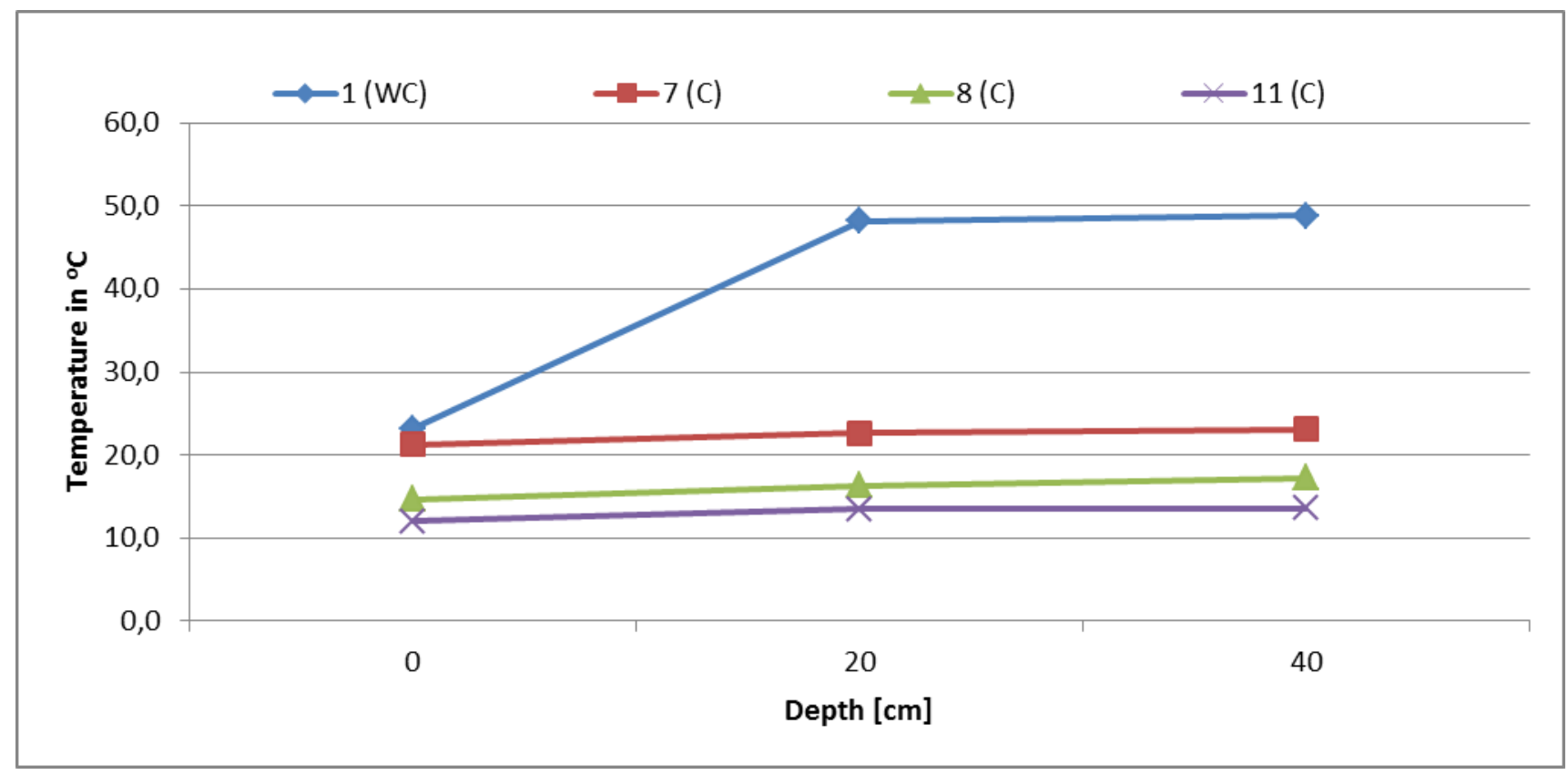

Figure 5 Bedding temperature at three depths for each farm 
The temperatures at depth of 20 and $40 \mathrm{~cm}$ clearly differ between the farm with composting wood chips and the other three with compost. Temperature during composting of wood chips reaches almost the $50^{\circ} \mathrm{C}$ where the temperature at these depths using compost do not differ from ambient temperature. 


\section{Conclusions}

- The ammonia emission per $\mathrm{m}^{2}$ area available for cows based on flux chamber measurements from a wood chips bedding was $190.4 \mathrm{mg} \mathrm{NH}_{3}$ per $\mathrm{m}^{2}$ per hour and for a compost bedding $372.8 \mathrm{mg}$ $\mathrm{NH}_{3}$ per $\mathrm{m}^{2}$ per hour including farm 11 and $537.1 \mathrm{mg} \mathrm{NH}_{3}$ per $\mathrm{m}^{2}$ per hour without farm 11.

- For farm 1,7 and 8 the emission per $\mathrm{m} 2$ per $\mathrm{h}$ is lower than the emission of ammonia from a reference system.

- The higher available area per cow however leads to a higher emission per cow .

- Nitrous oxide emissions were 3 to 26 times higher than the reference system.

- Methane emissions were on the other hand considerably lower than what could be expected from the reference system. 


\section{References}

De Boer, H.C. de (2013) On farm development of bedded pack dairy barns in The Netherlands. Nutrient balances and fertiliser value of bedding material. Wageningen UR Livestock Research, Livestock Research Report 709.

Mosquera, J. and J.M.G. Hol (2012) Emissiefactoren methaan, lachgas en PM2,5 voor stalsystemen, inclusief toelichting. Rapport 496, Wageningen UR Livestock Research, Lelystad.

Galama, P.J., H.J.C. van Dooren, H.C. de Boer, W. Ouweltjes, E.A.A. Smolders, K. Blanken en J.J. Poelarends (2012) Vrijloopstal Wiersma, Rapport 740, Wageningen UR Livestock Research, Lelystad.

Galama, P.J . (2013) On farm development of bedded pack dairy barns in The Netherlands Introduction and first experiences on three farms. Wageningen UR Livestock Research, Livestock Research Report 707.

Galama, P.J., Boer de, H.C., Dooren van, H.J.C., Ouweltjes, W., Driehuis, F. (2015) Sustainability aspects of 10 bedded pack dairy barns in The Netherland. Wageningen UR Livestock Research, Livestock Research Report 873

Van Dooren, H.J.C. van, P.J. Galama, M.C.J. Smits, W. Ouweltjes, F. Driehuis, S. Bokma (2012) Bodems voor vrijloopstallen. Onderzoek en ervaringen op proef- en praktijkbedrijven, Rapport 411, Wageningen UR Livestock Research, Lelystad. 

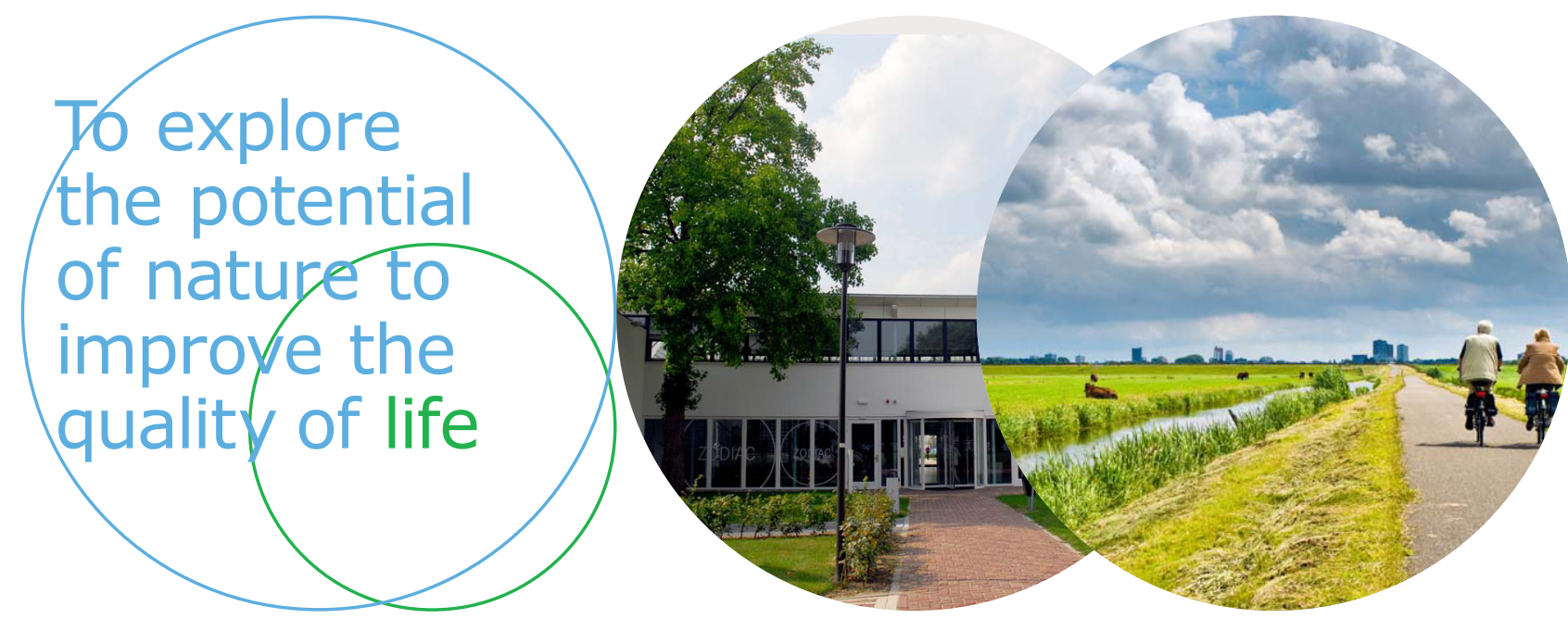

Wageningen Livestock Research P.O. Box 338

6700 AH Wageningen

The Netherlands

T +31 (0)317483953

E info.livestockresearch@wur.nl

www.wur.nl/livestock-research

Together with our clients, we integrate scientific know-how and practical experience to develop livestock concepts for the 21st century. With our expertise on innovative livestock systems, nutrition, welfare, genetics and environmental impact of livestock farming and our state-of-the art research facilities, such as Dairy Campus and Swine Innovation Centre Sterksel, we support our customers to find solutions for current and future challenges.

The mission of Wageningen University \& Research is 'To explore the potential of nature to improve the quality of life'. Within Wageningen University, nine specialised research institutes of the DLO Foundation have joined forces with Wageningen University to help answer the most important questions in the domain of healthy food and living environment. With approximately 30 locations, 6,000 members of staff and 10,000 students, Wageningen University is one of the leading organisations in its domain worldwide. The integral approach to problems and the cooperation between the various disciplines are at the heart of the unique Wageningen Approach. 